\title{
20 GODINA O \\ DEZINFORMACIJAMA, KRIVOTVORINAMA I MEDIJSKIM \\ MANIPULACIJAMA
}

\author{
Roman Domović*
}

\section{Uvod}

Dopala me čast da napišem tekst povodom dvadesete obljetnice izlaska časopisa National Security and the Future. Budući da sam i sam u njemu objavio nekoliko radova čija je tematika bila analiza medijskih manipulacija vezanih uz predsjednika Tuđmana i Domovinski rat, osvrt na časopis dat ću iz toga kuta i izdvojiti neke članke koji su pridonijeli boljem razumijevanju određenih događaja. Časopis National Security and the Future otvorio je vrata objavljivanju znanstvenih i stručnih radova koji u okviru različitih znanstvenih područja proučavaju tematiku stvaranja lažne realnosti o događajima iz Domovinskog rata i nasuprot tome predstavljaju činjenice. Osim toga, u časopisu su objavljeni i ranije neobjavljeni dokumenti iz arhiva predsjednika Tuđmana kao i dokumenti koji se nalaze u arhivi Haaškoga suda, ali sada lakše dostupni putem mrežnih stranica časopisa i portala hrvatskih znanstvenih i stručnih časopisa Hrčak.

* Dr. sc. Roman Domović, is a lecturer at the Zagreb University of Applied Sciences at the Department of Information Technology and Computing. He went to $X$. mathematical gymnasium where he graduated physics, after which he attended University of Zagreb and graduated in the field of Information sciences and Phonetics. At the same university he earned his doctoral degree in the field of Information and Communication sciences. His research interests are applied cryptography, classical cryptography and information warfare. He is an author of several scientific and professional articles in the field of Information and Communication sciences. 


\section{Unacceptable Lightness of "Historicism"}

Već je prvi broj časopisa koji je izašao 18. travnja 2000. objavio rad The War in Bosnia and Herzegovina or the Unacceptable Lightness of "Historicism", domaćeg povjesničara Domovinskog rata Davora Marijana, koji kaže da jedina mogućnost razumijevanja konflikta u BiH ide putem činjenica, a ne predrasuda. Rad se uglavnom temelji na dotad neobjavljenim i necitiranim dokumentima sva tri konstitutivna naroda u $\mathrm{BiH}$, čime autor postavlja činjenice nasuprot naširoko prihvaćenim tezama temeljenim na pristranim novinskim člancima. Time je časopis National Security and the Future otvorio vrata ne samo znanstvenim $\mathrm{i}$ stručnim krugovima, nego i širokoj javnosti da ratna događanja na područjima Hrvatske i Bosne i Hercegovine sagledavaju iz znanstvenoga kuta, obrađena znanstvenom metodologijom, a ne samo iz kuta iluzionista i njihove lažne realnosti koja je pogotovo nakon 2000. dominirala javnim prostorom.

Doprinos razumijevanju događaja iz Domovinskog rata dala je i studija slučaja o Operaciji Medački džep objavljena na engleskom i hrvatskom jeziku (svezak 3, broj 3-4, 2002., svezak 4, broj 1-4, 2003. i svezak 5, broj 1-4, 2004.) čiji je autor Miroslav Međimorec. Tu bi trebalo istaknuti nepostojeću bitku Hrvatske vojske s pripadnicima kanadskog bataljuna stacioniranog u Medačkom džepu. Taj slučaj trebalo bi ponovno istražiti danas u nadi da je u međuvremenu dostupno još materijala. Radi se o tome da su kanadski vojnici koji su bili stacionirani u Metku dobili odlikovanja za ,junačko ratovanje za vrijeme operacije Medački džep“ u "najvećoj kanadskoj bitci od Korejskog rata", a ta bitka bila je sukob s Hrvatskom vojskom. Kanađani tvrde da su u toj bitci ubili između 27 i 31 pripadnika HV-a te da su sami imali četvoricu ranjenih. Priča je čak opisana i u knjigama poput Tested Mettle: Canada's Peacekeepers at War autora Scotta Taylora i Briana Nolana iz 1999. te The Ghosts of Medak Pocket: The Story of Canada's Secret War iz 2005., kanadske novinarke Carol Off. Cijela ta kanadska priča lažna je jer nikakve takve bitke nije bilo. Nije pronađena ni dokumentacija koja bi potvrdila priču o ovoj bitci niti pouzdana svjedočanstva, ali je pronađena dokumentacija koja potvrđuje da se ova bitka nikada nije dogodila, a pronađena su i takva svjedočanstva.

Prema dosad analiziranim materijalima, postoje naznake da je ova lažna priča nastala kao posljedica spleta interesa više strana uključenih u priču: kanadske, srpske i francuske. Kanadski interesi imaju veze $s$ njhovim internim državnim 
političko-vojnim interesima koji zapravo i nemaju veze $\mathrm{s}$ njihovim mandatom u Hrvatskoj. Srpski su interesi prebaciti odgovornost za ratove na području bivše Jugoslavije sa sebe na druge ili in barem izjednačiti pa sve što je protiv Hrvatske i Hrvatske vojske, dobrodošlo im je. Francuski interesi povezani su s događajima za vrijeme i nakon operacije Maslenica gdje je došlo do neuspjeha pa i poniženja francuskog dijela UNPROFOR-a. Netko će ovaj navod proglasiti teorijom zavjere, ali on to nije. Za iscrpno i cjelovito obrazloženje trebalo bi napisati knjigu jer je toliko kompleksnih detalja nemoguće sažeti u ovaj osvrt, ali da bi se došlo do pretpostavki kako i zašto je nastala ova priča dovoljno je pregledati materijale dostupne na internetu i u manjem opsegu pa zainteresirani koji imaju volje i interesa mogu to napraviti.

Vrijedan doprinos sagledavanju cjelokupne slike rata u $\mathrm{BiH}$ su i dokumenti predsjedništva Bosne i Hercegovine 1991. 1994. objavljeni u osam brojeva izdanih u 2006. i 2007. Naime, iz određenih medijskih i političkih krugova plasiraju se teze iz kojih proizlazi da je događajima u ratu u $\mathrm{BiH}$ upravljala isključivo hrvatska vlast na čelu s predsjednikom Tuđmanom, kao da u svemu tome nisu sudjelovale srpska i bošnjačkomuslimanska strana te čitav niz međunarodnih čimbenika $\mathrm{s}$ različitim interesima u različitim razdobljima. Hrvatsku se optužuje za agresiju na $\mathrm{BiH}$, a nametanje takve teze ostvaruje se između ostalog i putem selektivnog medijskog prikaza dijelova transkripata isključivo hrvatske strane. Zbog toga je važno pokazati transkripte ostalih strana da se vidi da je Hrvatska morala plivati u moru različitih interesa svih strana uključenih u sukob odnosno rješavanje sukoba.

\section{O manipulaciji informacijama i plasiranju dezinformacija}

Za vrijeme suđenja generalima Gotovini, Markaču i Čermaku, iste interesne skupine koje su u medijskom prostoru nametale krivnju Hrvatske za agresiju na $\mathrm{BiH}$, trudile su se ocrniti i operaciju Oluja. U to vrijeme haaško tužiteljstvo surađivalo je sa srpskim obavještajnim službama i njihovim ekspoziturama, a neke od njih surađivale su s određenim pojedincima i organizacijama u Hrvatskoj, stvarajući lažne konstrukcije koje su Oluju trebale pretvoriti iz oslobodilačke operacije u zločinački pothvat, a hrvatsko državno vodstvo na čelu $s$ predsjednikom Tuđmanom te vojni i policijski vrh koji je vodio operaciju ratnim zločincima. Trebalo je osuditi Hrvatsku.

U proizvodnji laži manipuliralo se brojnim dokumentima, a najistaknutiji slučaj je tzv. Brijunski transkript, odnosno 
transkript sastanka predsjednika Tuđmana $s$ vojnim dužnosnicima, održanog 31. srpnja 1995. na Brijunima. Kao ultimativni dokaz da je na tom sastanku planirano etničko čišćenje Srba iz Hrvatske koristio se selektivno odabran fragment transkripta, odnosno rečenica: „Da nanesemo takve udarce da Srbi praktično nestanu, odnosno da ono što nećemo odmah zahvatiti da mora kapitulirati u nekoliko dana." $S$ tom rečenicom manipuliralo se na različite načine, a dva najčešća bila su izostavljanje drugog dijela rečenice „odnosno da ono što nećemo odmah zahvatiti da mora kapitulirati u nekoliko dana" da se stvori privid da se govori o civilima, a ne vojsci te u slučaju cijele rečenice uvjeravanje da se i dalje radi o civilima, iako je logičan zaključak da se govori o zadavanju udaraca srpskoj vojsci, a ne civilima jer kapitulira vojska. U svesku 11, broj 1 iz 2010. objavljen je cijeli Brijunski transkript pa su se čitatelji mogli uvjeriti i u cijeli kontekst sastanka te da na njemu nije bilo dogovoreno etničko čišćenje Srba. Ta priča rezultat je manipulativnog korištenja tog transkripta.

U svesku 11, broju 2-3 iz 2010. objavljena je moja analiza priloga u Dnevniku HTV-a od 20. studenog 2011. iz koje proizlazi da se gledateljstvo navodilo na pogrešne zaključke da hrvatsko državno vodstvo nije htjelo pomoći Vukovaru iako je moglo. Prilog se sastoji od spleta lažnih konstrukcija složenih pomoću tehnika manipulacije informacijama koje gledateljstvo dovode u zabludu i navode na pogrešne zaključke. U njemu su tri osnovna stupa za tzv. upravljanje percepcijom odnosno provođenje operacije utjecaja na temu Bitke za Vukovar:

1. Manipulacija Optužnicom koju je pročitao Siniša Glavašević, gdje se u prilogu daje sugestivan i činjenično netočan uvod, a autorstvo Optužnice pogrešno se imputira Siniši Glavaševiću te se mijenja kontekst vremena, događaja i prostora.

2. Manipulacija pokušajima proboja u Vukovar putem kojih se javnosti sugerira da su predsjednik Tuđman i državno vodstvo odustali od pomoći Vukovaru. U prilogu su događaji iz dva različita pokušaja proboja, od 13. listopada $i$ 12. studenog, spojena u jedan jedinstveni događaj. Uz naraciju novinara i svjedočanstvo generala Tusa, pomiješani su fragmenti iz ta dva proboja, vremenski razdvojena razdobljem od mjesec dana i sadržajno različita u događanjima na terenu te su onda ti izmiješani fragmenti predstavljeni kao jedan jedinstveni događaj. 
3. Tonski zapisi razgovora uglavnom predsjednika Tuđmana i Gojka Šuška s Mile Dedakovićem Jastrebom koji su montirani tako da slušateljima sugeriraju drugačiji tijek razgovora od originalnog i navode in na krive zaključke.

Nažalost, lažna priča plasirana $u$ tom prilogu $u$ nekim nerazumnim krugovima održala se do danas. Osim tog članka, objavljen je i članak dr. sc. Gordana Akrapa objavljen pod pseudonimom, koji pruža činjenice o toj famoznoj Optužnici te pokazuje da je ona iskorištena u svrhu ideološkog obračuna s predsjednikom Tuđmanom pri čemu je zanemarena istina o događajima u Vukovaru za vrijeme Domovinskog rata. Akrap smatra da mediji imaju bitan utjecaj na oblikovanje javnog znanja pojedinca te manjih i većih grupa i zajednica. Budući da se u medijima tumači prošlost i sadašnjost te predviđa budućnost, od strateške je važnosti da mediji budu, istinitim, objektivnim izvještavanjem uz primjenu i poštovanje etičkih načela, u službi općih interesa, pritom ne zanemarujući interese različitih manjinskih grupacija. No, na temelju analize određenih medijskih slučajeva Akrap smatra da su danas mediji, na žalost vrlo često, u funkciji nametanja percepcije umjesto znanja kao temelja za donošenje odluka različitih ciljanih publika tj. da percepcija prošlosti $\mathrm{i} / \mathrm{ili}$ stvarnosti koja se pokušava nametnuti nije ništa drugo nego preoblikovana istina u funkciji onemogućavanja postizanja spoznavanja stvarne istine.

U članku se zaključuje da "negativnu percepciju vukovarskih branitelja i stanovnika o drugim dijelovima Hrvatske, prvenstveno o državnoj vlasti i samom predsjedniku Tuđmanu, snažno su poticale i srbijanske protuobavijesti, prvenstveno one isplanirane u grupi Opera. Braniteljima $i$ stanovništvu je od strane srbijanskih propagandista, na žalost uspješno, nametnuta percepcija prema kojoj su 'ostavljeni, prodani, izdani od Zagreba' kao i neke druge kojima se pokušalo slomiti moral branitelja i ubrzati pad Vukovara." U javnosti se često manipuliralo i lzvješćem državne komisije o pripremi i vođenju obrane Vukovara, poznatijim kao Izvješće Manolićeve komisije, pa je u ovom broju objavljeno i cjelovito izvješće.

U 2013. objavljeno je još nekoliko mojih članaka, tada dijelova budućeg doktorata, a kasnije knjige U zasjedi dezinformacija. Prikazane su tehnike manipulacije informacijama kojima su stvorene nepostojeće karte o podjeli BiH između Hrvatske i Srbije kao i hrvatski medijski zametak lažne priče o podjeli $\mathrm{BiH}$ u Karađorđevu između predsjednika Tuđmana i Miloševića koja se od tada do danas širi javnim prostorom. 
Zatim problematika autentičnosti navodne Tuđmanove izjave o 200 obitelji koje će vladati hrvatskim gospodarstvom, gdje je analiza pokazala da u velikoj količini raznovrsnog materijala i svjedočanstava nije pronađena potvrda da je teza izrečena te da se stoga model hrvatskog gospodarstva temeljen na 200 bogatih obitelji ne može pripisati predsjedniku Tuđmanu. Tu je bila i detaljna razrada teze da je zbog hrvatske politike devedesetih prepolovljen broj Hrvata u $\mathrm{BiH}$. Pokazalo se da je ta izjava tadašnjeg predsjednika Josipovića neistinita i po razlozima za smanjenje broja Hrvata u $\mathrm{BiH}$ i po stvarnom broju Hrvata u BiH.

Kao doprinos razumijevanju događaja koji su se odvijali pri raspadu bivše Jugoslavije i osamostaljenju Hrvatske, u svesku 14, broj 3-4 i brojevima izdanim u 2014. objavljeni su transkripti sa sastanaka šestorice predsjednika republika te neki prateći dokumenti. Taj dotad nikad objavljeni materijal koji je deklasificiran na moj zahtjev, upotpunjuje sliku realnosti događaja prije i za vrijeme Domovinskog rata te istovremeno pokazuju neistinitost teza pomoću kojih se stvara lažna realnost o tim događajima. Taj materijal također pokazuje koliko je bitno da se umjesto selektivnog, fragmentarnog $i$ konstrukcijskog pristupa obradi informacija, istoj pristupa na cjelovit, sustavan, pouzdan i precizan način. Da bi to bilo moguće, nužno je da se znanstvenicima omogući uvid u dokumente iz vremena stvaranja hrvatske države, poglavito iz arhiva predsjednika Tuđmana.

\section{O tehnikama informacijskih operacija}

Brojevi iz 2015. donose članak posvećen teorijskom modelu provođenja informacijskih operacija. Poznavanje takve metodologije bitno je da bi se razumjelo fenomen stvaranja i širenja dezinformacija te provođenja informacijskih operacija i operacija utjecaja. To nije teorija zavjere nego stvarnost. Tu je i razrada principa i odrednica nacionalne strategije predsjednika Tuđmana te prikaz svih 48 sastanaka na kojima su se zajedno našli predsjednik Tuđman i Milošević. Upravo su proizvoljne interpretacije tih sastanaka ogledni primjer nerazumijevanja politike predsjednika Tuđmana. Na primjer, u iskazu danom haaškim istražiteljima, bivši hrvatski predsjednik Stipe Mesić rekao je da su susreti predsjednika Tuđmana i Miloševića "suludi“ i „apsurdni“. Mesić je izvlačio broj sastanaka iz konteksta u kojem su se oni događali i stavljao ih u lažni kontekst dogovora o podjeli Bosne i Hercegovine ili pak uspoređivao neusporedivo, kao npr. kako bi apsurdno bilo da su se Hitler i Churchill sastali toliko puta 
tijekom Drugog svjetskog rata, čime je falsificirao okolnosti i sadržaje tih sastanaka. Pregledom sastanaka vidi se da su Tuđman i Milošević na samo dva sastanka bili sami, u Karađorđevu 25. ožujka 1991. i Tikvešu 15. travnja 1991., a na svim ostalim sastancima bili su prisutni razni drugi sudionici tadašnjih događaja. Osim što su sastanci evidentno služili kao pokušaji razrješenja nastalih problema, služili su Tuđmanu i hrvatskoj strani za promatranje i prikupljanje informacija, kako o Miloševiću i srpskoj strani tako i svima ostalima koji su bili uključeni u tadašnje događaje, kao i za planiranje budućih akcija. Razvoj situacije koji je završio pobjedom Hrvatske i Tuđmanove politike i porazom Srbije i Miloševićeve politike, ali i svih onih domaćih i međunarodnih čimbenika koji su spletkarili protiv Hrvatske ili se otvoreno stavljali na srpsku stranu, dokazi su razboritosti $\mathrm{i}$ ispravnih odluka da se na tim sastancima sudjeluje.

Članak profesora Miroslava Tuđmana koji donosi pregled hrvatske nacionalne strategije 1990.-1999. kako ju je definirao predsjednik dr. Franjo Tuđman pokazuje promašenost teza i stajališta koje zastupa Stipe Mesić i krugovi oko njega. Tuđmanova strategija koja je vodila međunarodnom priznanju Republike Hrvatske, oslobađanju okupiranih teritorija i uspostavi mira u Bosni i Hercegovini temeljila se na filozofiji povijesti suvremene Europe i pravu naroda na samoodređenje. Za povjesničara dr. Franje Tuđmana, „što se svijet više integrira u civilizacijskom smislu, to se više individualizira u nacionalnom i političkom smislu“. Kao državnik Tuđman je svoju političku strategiju temeljio na sljedećim načelima: 1. Pravilo kontinuiranih interakcija i otvorene komunikacije što znači zagovaranje vlastitog stajališta, usklađivanje politike s međunarodnim standardima te kontinuirana interakcija koja je preduvjet pronalaska partnera i otvorene komunikacije za održavanje partnerstva s onima koji imaju iste ili slične interese. 2 . Strateško rješavanje problema: identifikacija i prioritizacija. tj. slijed političkih, diplomatskih ili vojnih poteza na nacionalnoj i međunarodnoj razini presudan je za uspjeh nacionalne strategije. 3. Pravilo neutralizacije neprijatelja izolacijom.

Za razliku od Tuđmanovih neistomišljenika koji su još i prije osamostaljenja, dok je Hrvatska bila slaba i u nepovoljnim međunarodnim okolnostima, tražili manje sastanaka i napad na JNA te kasnije odlučnije akcije nakon što su trećinu hrvatskog teritorija okupirale iste snage koje su držale kontrolu nad 2/3 teritorija Bosne i Hercegovine, strategija predsjednika Tuđmana nije bila fizički poraziti neprijatelje. Cilj je bio izolirati neprijatelja te pritom dovesti do toga da ga se 
osudi na političkoj, vojnoj i/ili međunarodnoj razini. Neutralizira se neprijatelj koji je izoliran u svojim željama, a njegov politički, diplomatski i vojni manevarski prostor je uzak, sveden na vlastite snage i stoga predvidiv.

\section{O Haškim presudama i činjenicama}

Godina 2017. donijela je logički i činjenično neshvatljivu presudu Haaškog suda šestorici $\mathrm{BiH}$ Hrvata u kojoj je potvrđen međunarodni oružani sukob u BiH te se potvrdilo postojanje hrvatskog udruženog zločinačkog pothvata s ciljem etničkog čišćenja dijelova BiH. U časopisu National Security and the Future objavljeni su tekstovi koji bacaju drugačije svjetlo na te presude. U svesku 18, broj 3 iz 2017. objavljeno je Izdvojeno i djelimično suprotno mišljenje sudije Jean-Claudea Antonettija, predsjedavajućeg Vijeća. Izdvojeno mišljenje ima 565 stranica pa ću iz njegove iscrpne analize izdvojiti samo njegov zaključak vezan za podjelu $\mathrm{BiH}$ te stvaranje Banovine Hrvatske (citat je prenesen iz tzv. BHS verzije napisane na haaškom sudu tj. osmišljenom bosanskom / hrvatskom / srpskom jeziku):

„Na osnovu svih tih elemenata može se vidjeti koliko mali značaj Tuđman pridaje Banovini kao političkom cilju. To se ogleda i u Ustavu Hrvatske koji je usvojen u decembru 1990. godine. Banovina se u njemu pominje u istorijskom kontekstu, a ne kao dio ustavnog korpusa. To je još jedan element koji dokazuje da Tuđman Banovini pridaje istorijsku, a ne političku vrijednost. $U$ tim okolnostima, meni je kao razumnom sudiji teško da se složim s tužilaštvom po pitanju udruženog zločinačkog poduhvata zasnovanog na obnavljanju Banovine u funkciji stvaranja 'Velike Hrvatske'."

Po pitanju udruženog zločinačkog pothvata, Antonetti je i tu jasan:

„Dakle, po mom mišljenju, jasno je da nije postojao nikakav udruženi zločinački poduhvat i da je, pored toga, došlo do 'distanciranja' između političara i vojske."

$\mathrm{U}$ istom broju objavljeno je i mišljenje odvjetnika Luke Mišetića koji je branio generala Gotovinu. Budući da se nakon presude u javnosti stvarala slika da je presudom presuđeno da je Franjo Tuđman ratni zločinac i djelitelj $\mathrm{BiH}$ te da je Hrvatska agresor na $\mathrm{BiH}$, Mišetić je dao svoju pravnu ekspertizu takvih tumačenja presude. Njegovi stavovi su da ni Raspravno niti Žalbeno vijeće nije utvrdilo postojanje bilo kakvih dokaza da su Tuđman, Šušak i Bobetko dijelili zajednički zločinački cilj počinjenja etničkog čišćenja te da 
Žalbeno vijeće nije razmatralo odgovornost hrvatskih dužnosnika. Mišetić smatra da nažalost dio nasljeđa Međunarodnog kaznenog suda za bivšu Jugoslaviju (MKSJa) jest također $i$ to da novinari, vlade, žrtve i javnost u cjelini rijetko čitaju presude MKSJ-a i dokaze na kojima se te presude temelje te da umjesto toga dojmovi o presudama MKSJ-a nastaju u minutama ili satima nakon izricanja presuda, često na temelju sažetaka presuda ili priopćenja za tisak od strane Tužiteljstva. Mišetić kaže da su sve presude javno dostupne kao i većina dokaza u predmetima na internetskim stranicama MKSJ-a. Zaključuje da javnost ima pravo, a možda i dužnost - ispitati presude i dokaze te da pod sunčevim svjetlom presuda u predmetu Prlić pokazuje da ne postoje uvjerljivi dokazi da su Tuđman, Šušak i Bobetko bili odgovorni za zločine počinjene u sklopu udruženog zločinačkog pothvata. A Tribunal nije donio potrebne izričite zaključke da jesu.

$\mathrm{U}$ istom broju svoj osvrt na presudu daje i prof. Miroslav Tuđman, a ovdje prenosim njegove završne riječi:

„Praljkov čin i sramotna presuda na koncu dvadeset i četiri godine postojanja Međunarodnog kaznenog tribunala za bivšu Jugoslaviju bit će politički alibi međunarodnim čimbenicima da je 'moć da se nešto učini' posredstvom Tribunala, u konkretnom predmetu bila tek sredstvo skidanja vlastitog dijela odgovornosti za nametanje mirovnih planova, ali i nespremnosti da svjedoče tko su im bili partneri a tko protivnici u provođenju potpisanih planova o BiH tijekom 1992.-1995. Presuda izrečena 29. studenog 2017. nije i neće pridonijeti političkoj stabilizaciji i mirnom suživotu u BiH, sve dok se na nju pojedine politike budu pozivale. Presuda neće biti kraj jednoga procesa, nego početak novih dugoročnih obračuna s onim Hrvatima koji zagovaraju opstojnost BiH kao države triju konstitutivnih naroda u kojoj i Hrvati moraju imati jednaka prava kao i druga dva naroda".

Za kraj dijela o presudi haaškog suda BiH šestorici, navest ću mišljenje Michaela G. Karnavasa, odvjetnika dr. Jadranka Prlića, objavljeno $u$ istom broju, o tom sudskom procesu $\mathrm{i}$ presudi:

„Istina jest da možda nisam najobjektivniji promatrač $i$ može se reći da imam interesa u ovom predmetu kojemu sam posvetio 12 godina svoje karijere. Kako god, mogu reći s punom odgovornošću da je ono što sam vidio tijekom suđenja bila parodija, šarada, teatar apsurda zamaskiran suđenjem. Svatko tko je bio na MKSJ-u to je 
vidio. Kao što sam ustrajno prigovarao sudcima tijekom suđenja, nitko od njih i nitko od sudaca na MKSJ-u ne bi želio da mu se sudi na način kako se sudilo mom branjeniku. Ako postoji jedan predmet, jedno suđenje $i$ jedan žalbeni postupak koji se ističe kao dio mračne ostavštine MKSJ-a, to je predmet Prlić i ostali. To je školski primjer kako ne treba voditi predmet, kako ne treba birati sudsko vijeće, kako ne treba voditi sudsku raspravu, kako ne treba analizirati dokazni materijal, kako ne treba pisati presudu."

Istom tematikom bavi se i svezak 19, broj 3 iz 2018. U tom broju objavljena su izlaganja pojedinih sudionika skupa "Ustavna država i haške presude" u organizaciji Udruge sv. Jurja (Zagreb, Matica Hrvatska 29. 11. 2018.) kako bi bili dostupni široj znanstvenoj i stručnoj javnosti. Na skupu su sudjelovali istaknuti pravnici $i$ povjesničari te raspravljali o pravnoj, političkoj i povijesnoj dimenziji suda u Haagu, kazneno-pravnim aspektima presude u slučaju Prlić i drugi, institutu udruženoga zločinačkog pothvata, sudskoj politici neprihvaćanja dokaza te vjerodostojnosti svjedoka.

Uvijek se može reći da su navedeni tekstovi pristrani jer su njihovi autori svaki na svoj način povezani s obranom šestorice BiH Hrvata. No jednako tako svatko može proći kroz dokumentaciju haaškoga suda, dokazni materijal, tužbe i presude. Osobno sam prošao kroz velik dio materijala. Kroz sav materijal vjerojatno je nemoguće proći zbog manjka vremena. Ali može se uzeti određena tematska cjelina pa proučiti materijal u okviru nje, a onda uzeti neku drugu i postupno širiti područje. lako nisam pravnik i područje prava mi je nepoznato, imam nekakvog znanja o znanstvenoj metodologiji i upravljanju informacijama i znanjem. Na temelju vlastite analize dosad proučenog materijala, mogu se samo složiti s autorima ovih tekstova. Nakon analize dostupnog materijala, logika i zdrav razum dovode do zaključka da te presude kao i slične teze plasirane iz određenih domaćih $i$ međunarodnih krugova koji su uvelike pomogli da do ovakvih presuda dođe, predstavljaju tendenciozno pa i zlonamjerno izvrtanje činjenica - ono što sam jednom prigodom nazvao inverzijom istine.

\section{Zaključno}

Na kraju ovog osvrta istaknuo bih kao i svaki puta kada pišem o ovim temama da je jedini pravi put $\mathrm{k}$ istinitom i objektivnom 
prikazu događaja iz Domovinskog rata korištenje znanstvene metodologije. Ni takav pristup ponekad nije imun na greške pa i pristranost, ali zbog prirode znanosti i znanstvene metodologije takvih stvari nema puno i lakše se mogu ispraviti od desetljećima nametanih lažnih konstrukcija koje se šire putem medija, a dolaze od raznih političkih, pseudoznanstvenih i medijskih krugova. Bilo bi izvrsno kada bi se stvorio lanac znanstvenici - znanstveno istraživanje rezultati - prezentacija rezultata u medijima. Nažalost, mediji nisu previše zainteresirani za rezultate znanstvenih istraživanja koja su tematski vezana uz Domovinski rat. $\mathrm{Ne}$ možemo reći da nisu zainteresirani uopće jer postoji određena količina članaka tog tipa, među kojima su i istraživanja objavljena u časopisu National Security and the Future, ali djeluje kao da okolnosti utječu na količinu, prigodu i način prenošenja. Daleko je više članaka napisanih proizvoljnim tumačenjem novinara ili prenošenjem teza nastalih u krugovima koji non stop dezinformiraju javnost. To bi mogla biti tema nekog budućeg istraživanja.

Primjetno je da se količina prenošenja rezultata znanstvenih istraživanja povećala nakon oslobađajuće presude generalima Gotovini, Markaču i Čermaku. Kao da su tim činom skinuti okovi koji su branili pisati činjenice nasuprot lažnim konstrukcijama. Šteta što politička korektnost i razni interesi i dalje često predstavljaju prepreku da se objavi tko je i zašto širio laži o Domovinskom ratu i predsjedniku Tuđmanu. No na kraju krajeva, bitna je sama priča, istinitost njezina sadržaja. Svaka od tih lažnih konstrukcija jednom puštena proširila se po medijima i javnosti pa je bitnije dekonstruirati samu laž i predstaviti istinu nego voditi bitke na osobnoj razini. To ne znači da uopće ne treba ukazivati i na autore lažnih konstrukcija. Kada se ukaže prilika, treba. Da javnost zna čije teze ne treba uzimati za ozbiljno.

Časopis National Security and the Future vrelo je znanstvenih, stručnih i ostalih članaka koji su dobro izbalansirali taj odnos. Vjerujem da će i u budućnosti National Security and the Future biti kvalitetan izvor činjenica vezanih uz Domovinski rat, ali i raznu drugu tematiku te da će objavljivanjem kvalitetnog materijala biti poticaj znanstvenicima i ostalim istraživačima te medijima da sudjeluju u oblikovanju javnog znanja na temelju znanstvene metodologije, činjenica i istine. 